\title{
Solirubrobacter soli sp. nov., isolated from soil of a ginseng field
}

Correspondence

Deok-Chun Yang

deokchunyang@yahoo.co.kr

\author{
Myung Kyum Kim, ${ }^{1}$ Ju-Ryun Na, ${ }^{1}$ Tae-Hoo Lee, ${ }^{1}$ Wan-Taek Im, ${ }^{2}$ \\ Nak-Kyun Soung ${ }^{3}$ and Deok-Chun Yang ${ }^{1}$ \\ ${ }^{1}$ Department of Oriental Medicinal Material and Processing, College of Life Science, Kyung \\ Hee University, 1 Seocheon-dong, Kiheung-gu Yongin, Kyunggi-do 449-701, South Korea \\ ${ }^{2}$ Environmental and Molecular Microbiology Laboratory, Department of Biological Sciences, \\ Korea Advanced Institute of Science and Technology (KAIST), 373-1 Guseong-dong, \\ Yuseong-gu, Daejeon 305-701, South Korea \\ ${ }^{3}$ Laboratory of Metabolism, Center for Cancer Research, National Cancer Institute, National \\ Institutes of Health, Bethesda, MD 20892, USA
}

A Gram-positive, non-spore-forming, rod-shaped and non-motile bacterium, strain Gsoil $355^{\top}$, was isolated from soil of a ginseng field in South Korea. In phylogenetic analyses based on 16S rRNA gene sequences, strain Gsoil $355^{\top}$ showed the highest levels of sequence similarity with respect to Solirubrobacter pauli B33D1 $1^{\top}(97.4 \%)$, Conexibacter woesei DSM $14684^{\top}(94.2 \%)$ and Patulibacter minatonensis $\mathrm{KV}-614^{\top}(91.8 \%)$. The strain possesses menaquinone MK-7 $\left(\mathrm{H}_{4}\right)$ and contains $\mathrm{C}_{16: 0}$ and $\mathrm{C}_{18: 0} \omega 9 \mathrm{c}$ as the predominant fatty acids. The DNA G+C content is $71.5 \mathrm{~mol} \%$. On the basis of genotypic and phenotypic characteristics, strain Gsoil $355^{\top}$ represents a novel species of the genus Solirubrobacter, for which the name Solirubrobacter soli sp. nov. is proposed. The type strain is Gsoil $355^{\top}\left(=\right.$ KCTC $12628^{\top}=$ LMG $\left.23485^{\top}\right)$.
Members of the phylum Actinobacteria are widespread in soils throughout the world. The genus Solirubrobacter and the species Solirubrobacter pauli were proposed by Singleton et al. (2003) for a member of the Actinobacteria isolated from a burrow of the earthworm Lumbricus rubellus in an agricultural soil in Georgia, USA (Furlong et al., 2002). A novel strain of this genus, Gsoil $355^{\mathrm{T}}$, was found in soil from a ginseng field in Daejeon, South Korea.

Strain Gsoil $355^{\mathrm{T}}$ was isolated by direct plating of the serially diluted soil sample onto R2A agar (Difco). Single colonies from these plates were transferred onto new plates and incubated for 5 days at $30^{\circ} \mathrm{C}$. The purified colonies were tentatively identified using partial $16 \mathrm{~S}$ rRNA gene sequences. Cell morphology and motility were investigated (using a Nikon light microscope at $\times 1000$ magnification) in a 5-day-old culture of Gsoil $355^{\mathrm{T}}$ grown on R2A agar at $30^{\circ} \mathrm{C}$. The Gram reaction was tested using the non-staining method, as described by Buck (1982). Oxidase activity was evaluated via the oxidation of $1 \% N, N, N^{\prime}, N^{\prime}$-tetramethyl$p$-phenylenediamine dihydrochloride. Catalase activity was determined by measuring bubble production after the

The GenBank/EMBL/DDBJ accession number for the 16S rRNA gene sequence of strain Gsoil $355^{\top}$ is AB245334.

The cellular fatty acid profiles of strain Gsoil $355^{\top}$ and related type strains are presented in a supplementary table available with the online version of this paper. application of $3 \%(\mathrm{v} / \mathrm{v})$ hydrogen peroxide solution to wellisolated colonies. Growth at a variety of temperatures $(4,15$, $25,30,37$ and $\left.42^{\circ} \mathrm{C}\right)$ and $\mathrm{pH}(5,5.5,6,6.5,7,7.5,8,8.5,9$ and 11) was assessed on R2A agar; the $\mathrm{pH}$ was adjusted by using $\mathrm{HCl}$ and $\mathrm{NaOH}$. Growth at various salt concentrations was tested by adding $0-10 \% \mathrm{NaCl}$ to $\mathrm{R} 2 \mathrm{~A}$ broth. The API 20NE, API ZYM and API ID 32GN microtest systems (bioMérieux) were used to analyse the physiological and biochemical characteristics, according to the recommendations of the manufacturer.

Isoprenoid quinones were extracted with chloroform/ methanol $(2: 1, \mathrm{v} / \mathrm{v})$, purified by TLC and then analysed by HPLC as described previously (Collins \& Jones, 1981; Shin et al., 1996). For analysis of the fatty acid methyl esters, the strain was grown on tryptic soy agar (Difco) for $48 \mathrm{~h}$ at $30^{\circ} \mathrm{C}$ and then two loops of the well-grown cells were harvested. Fatty acid methyl esters were prepared and identified using the Sherlock Microbial Identification System (MIDI) (Sasser, 1990).

The genomic DNA of strain Gsoil $355^{\mathrm{T}}$ was extracted and purified with Genomic-tip system 100/G (Qiagen). It was then enzymically degraded into nucleosides to determine the DNA G+C content (Tamaoka \& Komagata, 1984; Mesbah et al., 1989). DNA-DNA hybridization was performed according to the method developed by Ezaki et al. (1989). Hybridization was conducted using five replications for each sample. The highest and lowest values were 
excluded and the DNA relatedness taken from the mean of the remaining three values.

For analysis of the 16S rRNA gene sequence, genomic DNA was extracted and purified with a genomic DNA isolation kit (Core Bio System). The 16S rRNA gene was amplified using the universal bacterial primers $9 \mathrm{~F}$ and $1512 \mathrm{R}$ (Weisburg et al., 1991) and the purified PCR products were sequenced by Genotec (Daejeon, Korea) and then edited (Kim et al., 2005). The 16S rRNA gene sequences of related taxa were obtained from GenBank. Multiple alignments were performed with the CLUSTAL X program (Thompson et al., 1997). Evolutionary distances were calculated using the Kimura two-parameter model (Kimura, 1983). A phylogenetic tree was constructed using the neighbour-joining method (Saitou \& Nei, 1987) in the MEGA2 program (Kumar et al., 2001). A bootstrap analysis (based on 1000 replicates) was also performed (Felsenstein, 1985).

Strain Gsoil $355^{\mathrm{T}}$ produced non-pigmented colonies on R2A agar at $30{ }^{\circ} \mathrm{C}$. The strain comprised aerobic, Gram-positive, non-motile, rod-shaped bacteria. The optimal growth temperature was about $30^{\circ} \mathrm{C}$. No growth was observed within 7 days at $37^{\circ} \mathrm{C}$ and only weak growth occurred after 14 days at $15^{\circ} \mathrm{C}$. The physiological characteristics are summarized in the species description.

The 16S rRNA gene sequence-based phylogenetic analysis showed (Fig. 1) that strain Gsoil $355^{\mathrm{T}}$ is a member of the family Solirubrobacteraceae (Stackebrandt, 2004, 2005). The highest sequence similarities (97.4, 94.2 and $91.8 \%$ ) were found with respect to the type strains of $S$. pauli (Singleton et al., 2003), Conexibacter woesei (Monciardini et al., 2003) and Patulibacter minatonensis (Takahashi et al., 2006), respectively.

The cellular fatty acid profiles of strain Gsoil $355^{\mathrm{T}}$ and the related Solirubrobacter, Conexibacter and Patulibacter species are shown in Supplementary Table S1 (available in IJSEM Online). The major cellular fatty acids in strain Gsoil $355^{\mathrm{T}}$ included $\mathrm{C}_{16: 0}$ iso $(26.7 \%)$ and $\mathrm{C}_{18: 1} \omega 9 c(18.3 \%)$. Minor amounts of fatty acids $\mathrm{C}_{14: 0}(0.7 \%), \mathrm{C}_{14: 0}$ iso $(0.6 \%), \mathrm{C}_{15: 0}(1.9 \%), \mathrm{C}_{16: 0}(2.1 \%), \mathrm{C}_{17: 0}(5.3 \%), \mathrm{C}_{18: 0}$ $(3.3 \%), \mathrm{C}_{18: 0}$ iso $(4.3 \%), \mathrm{C}_{19: 0}(4.5 \%), \mathrm{C}_{20: 0}(1.1 \%)$, unsaturated fatty acids $\mathrm{C}_{16: 1}$ iso $\mathrm{H}(3.0 \%), \mathrm{C}_{16: 1} \omega 9 c$

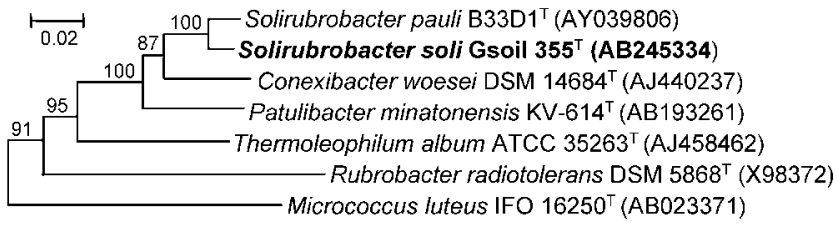

Fig. 1. Neighbour-joining phylogenetic tree, based on $16 \mathrm{~S}$ rRNA gene sequences, showing the relationships between strain Gsoil $355^{\top}$ and related species in the genera Solirubrobacter, Conexibacter and Patulibacter. Bar, 0.02 substitutions per nucleotide position.
(0.9\%), $\mathrm{C}_{17: 1} \omega 6 c(5.5 \%), \mathrm{C}_{17: 1} \omega 8 c \quad(4.3 \%), \mathrm{C}_{18: 3} \omega 6 c$ $(7.3 \%)$ and $\mathrm{C}_{20: 4} \omega 6,9,12,15 c(0.9 \%)$, summed feature 4 $\left(\mathrm{C}_{16: 1} \omega 7 c / \mathrm{C}_{15: 0}\right.$ iso $\left.2-\mathrm{OH} ; 1.4 \%\right)$ and summed feature 8 (unknown ECL 18.756/ $\mathrm{C}_{19: 1} \omega 11 c ; 7.9 \%$ ) were also detected. No significant differences were found between the fatty acid profiles of strain Gsoil $355^{\mathrm{T}}$ and S. pauli $\mathrm{B} 33 \mathrm{D} 1^{\mathrm{T}}$ (Singleton et al., 2003).

Strain Gsoil $355^{\mathrm{T}}$ contained a menaquinone with seven isoprene units $\left[\mathrm{MK}-7\left(\mathrm{H}_{4}\right)\right]$ as the predominant isoprenoid quinone.

The DNA G+C content of strain Gsoil $355^{\mathrm{T}}$ was $71.5 \mathrm{~mol} \%$. The strain exhibited $25.0 \%$ (mean of 22,29 and $27 \%$ ) DNA-DNA relatedness with respect to $S$. pauli ATCC BAA- $492^{\mathrm{T}}$. The level of relatedness was less than $70 \%$, which is considered to be the threshold for delineating a genomic species (Wayne et al., 1987). In addition, the strain could be readily distinguished from $S$. pauli at the phenotypic level (Table 1). The results of the polyphasic analysis clearly show that strain Gsoil $355^{\mathrm{T}}$ represents a novel species within the genus Solirubrobacter, for which the name Solirubrobacter soli sp. nov. is proposed.

\section{Description of Solirubrobacter soli sp. nov.}

Solirubrobacter soli (so'li. L. neut. gen. n. soli of soil, the source of the type strain).

Cells are Gram-positive, aerobic, non-motile, nonpigmented rods. Growth occurs on $\mathrm{R} 2 \mathrm{~A}$ agar at $30^{\circ} \mathrm{C}$. Good growth is observed at 25 and $30^{\circ} \mathrm{C}$. Growth occurs at $0-1.5 \%(\mathrm{w} / \mathrm{v}) \mathrm{NaCl}$ but not at higher salt concentrations. Catalase-positive and weakly oxidase-positive. $N$-Acetyl- $\beta$ glucosaminidase, acid phosphatase, alkaline phosphatase,

Table 1. Comparison of phenotypic characteristics of strain Gsoil $355^{\top}$ and S. pauli ATCC BAA $-492^{\top}$

Data for S. pauli ATCC BAA $-492^{\mathrm{T}}$ were taken from Singleton et al. (2003). Both strains were Gram-positive, non-motile rods and both were catalase-positive and unable to grow with more than $1.5 \% \mathrm{NaCl}$. Both strains could utilize mannose and sucrose and neither could utilize citrate, 3-hydroxybenzoate, malate or mannitol. +, Positive; - , negative; $\mathrm{w}$, weakly positive.

\begin{tabular}{|c|c|c|}
\hline Characteristic & $\begin{array}{l}\text { Gsoil } \\
355^{\mathrm{T}}\end{array}$ & $\begin{array}{l}\text { S. pauli ATCC } \\
\text { BAA }-492^{\mathrm{T}}\end{array}$ \\
\hline Cell length $(\mu \mathrm{m})$ & $1.0-3.0$ & 1.4 \\
\hline Colony colour & White & Pink \\
\hline Oxidase activity & $\mathrm{W}$ & - \\
\hline Growth at $1 \% \mathrm{NaCl}$ & + & - \\
\hline \multicolumn{3}{|l|}{ Utilization of carbon sources } \\
\hline Acetate & - & + \\
\hline D-Sorbitol & - & + \\
\hline L-Alanine & - & + \\
\hline DNA G $+C$ content $(\mathrm{mol} \%)$ & 71.5 & 71.8 \\
\hline
\end{tabular}


cystine arylamidase, esterase (C4), esterase (C8), $\alpha$-glucosidase, $\beta$-glucosidase, $\beta$-galactosidase, leucine arylamidase and valine arylamidase are produced. Arginine dihydrolase, $\alpha$-chymotrypsin, $\alpha$-fucosidase, $\alpha$-galactosidase, $\beta$-glucuronidase, lipase (C14), $\beta$-mannosidase, naphthol-AS-BIphosphohydrolase, trypsin and urease are not produced. Gelatin is hydrolysed. Adipate, gluconate, L-arabinose, L-fucose, D-glucose, D-maltose, D-melibiose, L-rhamnose, D-ribose, sucrose, myo-inositol, L-proline, $\mathrm{N}$-acetyl-Dglucosamine, salicin and glycogen are utilized as sole carbon sources. 2-Ketogluconate, 3-hydroxybenzoate, 3hydroxybutyrate, 4-hydroxybenzoate, 5-ketogluconate, acetate, caprate, citrate, itaconate, lactate, L-malate, malonate, phenyl acetate, propionate, suberate, $n$-valerate, $\mathrm{D}$ mannitol, D-sorbitol, L-alanine and L-histidine are not utilized as sole carbon sources. No reduction of nitrate to nitrite or nitrogen gas occurs. The DNA G $+\mathrm{C}$ content is $71.5 \mathrm{~mol} \%$ (HPLC). The predominant quinone is MK$7\left(\mathrm{H}_{4}\right)$. The major cellular fatty acids are $\mathrm{C}_{16: 0}$ iso $(26.7 \%)$ and $\mathrm{C}_{18: 1} \omega 9 c(18.3 \%)$.

The type strain, Gsoil $355^{\mathrm{T}}\left(=\mathrm{KCTC} 12628^{\mathrm{T}}=\mathrm{LMG}\right.$ $\left.23485^{\mathrm{T}}\right)$, was isolated from soil from a ginseng field in Daejeon, South Korea.

\section{Acknowledgements}

This work was supported by a grant from the Plant Diversity Research Center of the 21st Century Frontier Research Program (code PF0622200) funded by the Ministry of Science and Technology of the Korean Government and by a BK21 research fellowship from the Korean Ministry of Education and Human Resource Development.

\section{References}

Buck, J. D. (1982). Nonstaining (KOH) method for determination of Gram reactions of marine bacteria. Appl Environ Microbiol 44, 992-993.

Collins, M. D. \& Jones, D. (1981). Distribution of isoprenoid quinone structural types in bacteria and their taxonomic implications. Microbiol Rev 45, 316-354.

Ezaki, T., Hashimoto, Y. \& Yabuuchi, E. (1989). Fluorometric deoxyribonucleic acid-deoxyribonucleic acid hybridization in microdilution wells as an alternative to membrane filter hybridization in which radioisotopes are used to determine genetic relatedness among bacterial strains. Int J Syst Bacteriol 39, 224-229.

Felsenstein, J. (1985). Confidence limits on phylogenies: an approach using the bootstrap. Evolution 39, 783-791.

Furlong, M. A., Singleton, D. R., Coleman, D. C. \& Whitman, W. B. (2002). Molecular and culture-based analyses of prokaryotic communities from an agricultural soil and the burrows and casts of the earthworm Lumbricus rubellus. Appl Environ Microbiol 68, 1265-1279.

Kim, M. K., Im, W.-T., Ohta, H., Lee, M. \& Lee, S.-T. (2005). Sphingopyxis granuli sp. nov., a $\beta$-glucosidase-producing bacterium in the family Sphingomonadaceae in $\alpha-4$ subclass of the Proteobacteria. J Microbiol 43, 152-157.

Kimura, M. (1983). The Neutral Theory of Molecular Evolution. Cambridge: Cambridge University Press.

Kumar, S., Tamura, K., Jakobsen, I.-B. \& Nei, M. (2001). MEGA2: molecular evolutionary genetics analysis software. Bioinformatics 17, 1244-1245.

Mesbah, M., Premachandran, U. \& Whitman, W. B. (1989). Precise measurement of the $\mathrm{G}+\mathrm{C}$ content of deoxyribonucleic acid by highperformance liquid chromatography. Int J Syst Bacteriol 39, 159-167.

Monciardini, P., Cavaletti, L., Schumann, P., Rohde, M. \& Donadio, S. (2003). Conexibacter woesei gen. nov., sp. nov., a novel representative of a deep evolutionary line of descent within the class Actinobacteria. Int J Syst Evol Microbiol 53, 569-576.

Saitou, N. \& Nei, M. (1987). The neighbor-joining method: a new method for reconstructing phylogenetic trees. Mol Biol Evol 4, 406-425.

Sasser, M. (1990). Identification of bacteria by gas chromatography of cellular fatty acids, MIDI Technical Note 101. Newark, DE: MIDI Inc.

Shin, Y. K., Lee, J.-S., Chun, C. O., Kim, H.-J. \& Park, Y.-H. (1996). Isoprenoid quinone profiles of the Leclercia adecarboxylata KCTC $1036^{\mathrm{T}}$. J Microbiol Biotechnol 6, 68-69.

Singleton, D. R., Furlong, M. A., Peacock, A. D., White, D. C., Coleman, D. C. \& Whitman, W. B. (2003). Solirubrobacter pauli gen. nov., sp. nov., a mesophilic bacterium within the Rubrobacteridae related to common soil clones. Int J Syst Evol Microbiol 53, 485-490.

Stackebrandt, E. (2004). Will we ever understand? The undescribable diversity of the prokaryotes. Acta Microbiol Immunol Hung 51, $449-462$.

Stackebrandt, E. (2005). Solirubrobacteraceae fam. nov. In Validation of the Publication of New Names and New Combinations Previously Effectively Published Outside the IJSEM, List no. 102. Int J Syst Evol Microbiol 55, 547-549.

Takahashi, Y., Matsumoto, A., Morisaki, K. \& Ōmura, S. (2006). Patulibacter minatonensis gen. nov., sp. nov., a novel actinobacterium isolated using an agar medium supplemented with superoxide dismutase, and proposal of Patulibacteraceae fam. nov. Int J Syst Evol Microbiol 56, 401-406.

Tamaoka, J. \& Komagata, K. (1984). Determination of DNA base composition by reversed phase high-performance liquid chromatography. FEMS Microbiol Lett 25, 125-128.

Thompson, J. D., Gibson, T. J., Plewniak, F., Jeanmougin, F. \& Higgins, D. G. (1997). The CLUSTAL_X windows interface: flexible strategies for multiple sequence alignment aided by quality analysis tools. Nucleic Acids Res 25, 4876-4882.

Wayne, L. G., Brenner, D. J., Colwell, R. R., Grimont, P. A. D., Kandler, O., Krichevsky, M. I., Moore, L. H., Moore, W. E. C., Murray, R. G. E. \& other authors (1987). International Committee on Systematic Bacteriology. Report of the ad hoc committee on reconciliation of approaches to bacterial systematics. Int $J$ Syst Bacteriol 37, 463-464.

Weisburg, W. G., Barns, S. M., Pelletier, D. A. \& Lane, D. J. (1991). $16 \mathrm{~S}$ ribosomal DNA amplification for phylogenetic study. J Bacteriol 173, 697-703. 